\title{
Research on the Interaction between Producer Services and Manufacturing Industry in Shaanxi Province
}

\author{
Lingyi Kong, Xiao Liang \\ Xi'an University of Posts and Telecommunications, Xi'an, China \\ Email: 283857480@qq.com
}

How to cite this paper: Kong, L.Y. and Liang, X. (2018) Research on the Interaction between Producer Services and Manufacturing Industry in Shaanxi Province. American Journal of Industrial and Business Management, 8, 1277-1289.

https://doi.org/10.4236/ajibm.2018.85087

Received: April 8, 2018

Accepted: May 19, 2018

Published: May 22, 2018

Copyright ( 92018 by authors and Scientific Research Publishing Inc. This work is licensed under the Creative Commons Attribution International License (CC BY 4.0).

http://creativecommons.org/licenses/by/4.0/

\begin{abstract}
With the deepening of social division of labor, producer services are gradually separated from manufacturing industry and play a more and more important role in the national economy. In particular, with the rapid development of scientific research, business, law, finance and other industries, the industrial association between the productive service industry and the manufacturing industry becomes more closely. The interactive state between the producer services and manufacturing industry has a direct impact on the industrial upgrading and structural adjustment of all sectors of the national economy, which has become an important way for the economic development of our country in the future. Taking Shaanxi Province as an example, this paper first analyzes the development of producer services and manufacturing in Shaanxi. On this basis, the VAR model is built to analyze the added value of two industries in Shaanxi Province. Finally, according to the empirical results, we put forward relevant countermeasures and suggestions.
\end{abstract}

\section{Keywords}

Productive Service Industry, Manufacturing Industry, Interaction, Shaanxi Province

\section{Introduction}

In the context of the transformation of the global industrial structure from "industrial economy" to "service-oriented economy", the productive service industry will become the pillar industry of the national economic development. According to the data released by the National Bureau of statistics, in 2017, China's service industry added 427,032 billion yuan, accounting for 51.6\% of GDP, a 
11.1 percentage point higher than the second industry, becoming the first major industry in China. The added value of service industry increased by $8 \%$ over the previous year, which is 1.1 percentage points higher than the national GDP growth rate. The growth rate in the 5 consecutive years is higher than that in the second industry. In 2017, the national development and Reform Commission issued the outline of innovation and development of service industry (2017 to 2025). It is clearly pointed out in the outline that China will achieve an increase of ten years in service industry on the basis of optimizing structure, improving quality and enhancing efficiency by the end of 2025. By then, the added value of service industry will account for $60 \%$ of GDP and the proportion of employed population in the whole society will reach $55 \%$.

As a major province of education and a resource province, Shaanxi has also taken some measures in promoting the development of producer services, and has made some achievements. In the name of "China made 2025 " issued by the Shaanxi provincial, developing service manufacturing and promoting the deep integration of manufacturing and service industry have been an important strategic task. From 2004 to 2014, the added value of producer services in Shaanxi increased by more than 4 times. The added value of financial industry, retail industry and transportation industry increased by 9.5, 3.5 and 1.5 times respectively. The development of financial industry is most rapid, and its annual development speed is far beyond the overall level of the province's economy. Although the productive service industry in Shaanxi is developing rapidly, there are still many problems, such as small enterprises, weak foundation and lack of awareness of innovation. It also directly leads to the integration and promotion of the manufacturing industry.

Therefore, this paper, based on the development of Shaanxi's productive service industry and manufacturing industry, explores the interactive relationship between the major subdivision industries and the manufacturing industry in Shaanxi's productive service industry through the construction of the VAR model. The article is organized as Figure 1.

In the research significance, the empirical study of this paper will help to make up for the shortage of this problem, and provide an important theoretical basis for the industrial development and structural transformation of Shaanxi Province, and help Shaanxi to formulate specific policies to promote industrial development. At the same time, it can also provide reference for other regions' coordinated development of producer services and manufacturing.

However, the interactive development of manufacturing and production services is a complex process. Due to the lack of individual research level, the research conditions and resources are limited, and there are still a lot of shortcomings in the paper. For example, because of the limitation of data acquisition, based on the availability of data, this paper only chooses 4 industries as the research object of the productive service industry. The calculation of the added value of the manufacturing industry is only a summary of the statistical data, but 


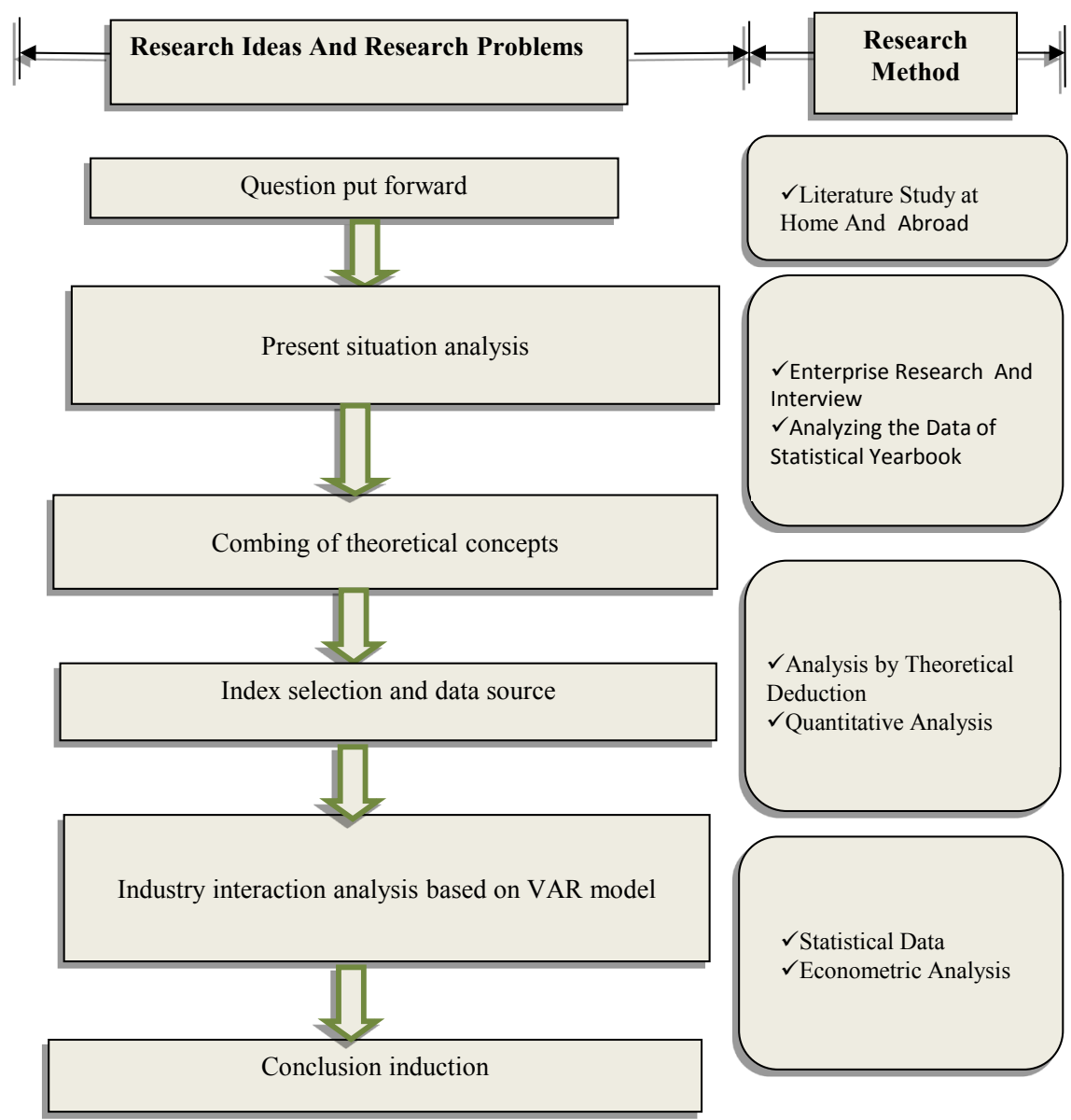

Figure 1. Article framework.

even the data of the statistical yearbook is difficult to achieve in full. Therefore, the results of the analysis will inevitably have small deviations.

\section{Concept Review}

After 1980s, the service industry has gradually become the most dynamic department in various countries. The proportion of the output value of service industry is becoming more and more large. Foreign scholars began to study the problems related to the development of manufacturing industry and manufacturing industry in the macro level. Among them, the relationship between the productive service industry and the manufacturing industry is the hot spot of the scholars' research. The research on the relationship between the two is evolving and more controversial in accordance with the development of the productive service industry. At present, according to their subordinate status the popular claim about the relationship between the two is divided: demand compliance, supply leadership and interaction theory [1].

\subsection{Demand Compliance Theory}

This view is that demand creates supply, and the development of producer ser- 
vices originates from the demand for services caused by manufacturing expansion. Therefore, only when the degree of industrialization and urbanization is high, the effective demand for the products of the productive service industry can be formed, so that the production resources will be inflow into the productive service sector and the division of labor is deepened and the efficiency is increased, so it can be developed. Karaomerliojlu and Carlsson (1999) empirically analyzed the intermediate consumption of American manufacturing industry to production service products [2]. The results showed that the consumption of manufacturing services in the United States increased by about $100 \%$ in the 1987-1994 years, accounting for about 50\% of the total output of the productive service industry. Klodt (2000) found that the development of the production service industry has a great relationship with the manufacturing industry by studying the factors that affect the development of the production service industry [3]. Most of the factors that affect the production service industry are from the manufacturing industry.

\subsection{Supply Leading Theory}

This view is derived from the classic conclusion, "supply creates demand". It is considered that service industry is the premise and foundation for improving the productivity and development level of manufacturing industry. Without enough cash supply of productive services, there will be no competitive manufacturing sector. Markusen (1989) introduced producer services as an intermediate input model, and analyzed the inherent mechanism of producer services promoting manufacturing and economic growth [4]. Juleff (1996) thinks that the development motive of the productive service industry is mainly from the inside of the enterprise, because in the process of providing service for industry, it will continue to derive the logistics, electronic commerce, finance and other industries, and make the productive service industry develop [5]. Eswaran and Kotwal (2001) studied the role of producer services in manufacturing industry in the process of industrialization [6]. They believe that producer services are the links between consumers and industrial producers. The development of service industry is conducive to the establishment of a complete industrial chain in manufacturing industry.

\subsection{Interactive Development Theory}

This view is the integration of "demand theory" and "supply theory", and thinks that the productive service industry and manufacturing industry are the relationship of interaction, the manufacturing sector provides demand for the productive service sector, the producer services provide products for the manufacturing industry, and the producer services and manufacturing industry develops together in the interaction and cooperation. Beyers (2005) studies the relationship between producer services and manufacturing in the process of technology transfer by empirical methods [7]. As a result of the expansion of demand in the manufacturing industry, the number of employees in the advertising, marketing, 
computer applications and voice communications sectors in the production service industry has increased significantly. Lundquist, Olander and Henning (2008) use Swedish longitudinal data from eight different service industries to study the role of Swedish producer services in economic transformation [8]. The research shows that the development of the productive service industry has gradually replaced the position of the manufacturing industry in the economy, and the output value and technology content of the productive service industry have made great progress, and the various departments within the productive service industry are also growing at a high speed.

It can be found that the above research has the following shortcomings:

1) The perspective of research is single. The interaction mechanism between producer services and manufacturing industry is systematically studied from the perspective of value chain.

2) Limitations of empirical methods. Most of the research uses the input-output method. However, the input-output economic model only investigates short-term and static interaction, and cannot capture the long-term dynamic relationship between them.

Therefore, this paper is based on the value chain perspective to explore the interaction mechanism of the productive service industry and manufacturing industry, based on this, based on the development status of the productive service industry and manufacturing industry in Shaanxi province and the data of the previous years, the quantitative model is constructed, and the interaction relationship between the industries is verified.

\section{Interactive Relationship Based on the Perspective of Value Chain}

The concept of value chain was first introduced in 1980s, and Michael Poti came it out with the popularity of multinational companies. In the "competitive advantage", he points out that the productive operations of each enterprise are made up of a number of independent production departments or production links, and a complete production activity includes many production activities such as R\&D design, material purchase, manufacturing, packaging planning, advertising marketing, material flow distribution, after service and so on. It also involves a series of operation and management departments, such as technology research and development, procurement management, financial budget, quality progress control and so on. These productive activities and supporting activities constitute the value chain of the enterprise together.

Zheng Jichang and Xia Qing (2005), based on the value chain, divided the manufacturing activities of enterprises into 3 links, such as upper, middle and lower, and the production service activities such as logistics transportation, advertising planning and after-sales service are divided into lower links, and production and manufacturing are the middle reaches [9]. With the increasing competition in the market, the role of the productive service industry in each 
link of the value chain is becoming more and more important. It promotes the smooth integration of production capital such as manpower, knowledge, technology and capital into the production process. It is the source of improving production efficiency and product value. It is also the difference and important factor of each product.

\section{Empirical Analysis}

\subsection{Model Establishment}

\subsubsection{Index Selection and Data Source}

This paper selects the 4 value-added industries of Shaanxi manufacturing industry from 1997 to 2016, including the total value added value of manufacturing industry (100 million yuan) and the producer services sector (100 million yuan) as the research object. The sample data of this chapter comes from the statistical yearbook of Shaanxi province from 1998 to 2017. The added value of the manufacturing industry is added to the annual increment of the manufacturing industry, due to the changes in the statistical calibre in the statistical yearbook. The 4 value-added of producer services is from 1998 to 2017, Shaanxi statistical yearbook. For the operability of the model, 4 selected industries that represent the characteristics of producer services are selected. See Figure 2. The statistical software Eviews9.0 is used as an analytical tool.

Through the investigation of the interactive relationship between the subdivision of the production service industry and the variables in the manufacturing industry, it can well reflect the interactive relationship between producer services and manufacturing industry in the value chain and the quantitative results.

\subsubsection{The Construction of the Model}

This article draws on the corresponding matching between the industrial division of the productive service industry and the value chain of the manufacturing industry, and selects the production service industry and the manufacturing industry data as input data. We use ADF stationarity test, cointegration test and impulse response analysis to establish the VAR model, and test the interaction effect between them.

The mathematical expressions of the VAR model are as follows:

$$
y_{n}=B_{0}+A_{1} y_{n-1}+\cdots+A_{p} y_{n-p}+B X_{n}+e_{n}(n=1,2, \cdots, N)
$$

Among them, $B_{0}$ is intercept term vector, $A_{i}$ is a polynomial matrix of

\begin{tabular}{lcc}
\hline Value Chain & $\begin{array}{c}\text { Type of } \\
\text { production department }\end{array}$ & Selection of indicators \\
\hline Upper reaches & $\begin{array}{c}\text { Scientific and } \\
\text { technological services }\end{array}$ & $\begin{array}{c}\text { Scientific research and } \\
\text { technical service industry }\end{array}$ \\
Middle reaches & Financial service & Financial industry Real estate industry \\
Downstream & Circulation service & Transportation, warehousing and postal services
\end{tabular}

Figure 2. Classification and scope of the productive service industry. 
$y_{n-i}, y_{n}$ is a $\mathrm{K}$ variable dimension vector, $X_{n}$ is an extrinsic vector variable of $\mathrm{D}$ dimension, $p$ is a lagging order, is an error term with a mean of 0 .

\subsection{Empirical Test}

\subsubsection{ADF Unit Root Test}

Definition of time series stationarity: suppose that a time series is generated by a random process. That is, the time series is assumed to be $\left\{X_{t}\right\}(t=1,2, \cdots)$. Suppose that every value of this series is obtained from a probability distribution. If $X_{t}$ meets the following conditions:

1) The mean $E\left(X_{t}\right)=m$ is a constant that is independent of time;

2) The variance $\operatorname{Var}\left(X_{t}\right)=s^{2}$ is a constant unrelated to the time $\mathrm{t}$;

3) Covariance $\operatorname{Cov}\left(X_{1}, X_{1+k}\right)=g_{k}$ is related to interval time and time independent constants.

It is called that the time series generated by this stochastic process is stationary.

In order to avoid the pseudo regression phenomenon when the single whole sequence is tested, this paper first tests the variables of each time series by ADF unit root test, in order to determine the stability of the relationship between the variables of each time series. If a time series is stationary, then the mean and variance of this sequence will not change with time and be bounded.

If the time series is nonstationary, the difference can be processed. Generally speaking, a non-stationary sequence can be transformed into a stationary sequence after $\mathrm{n}$ difference processing. It is called $\mathrm{n}$ order single integer sequence, and is written as $\mathrm{L}(\mathrm{n})$.

Figure 3 is the result of every unit root run by Eviews9.0. It can be seen from the table that the sequence of the original data is not smooth and needs to be differentiated. After a difference, it is found that $\ln x 1, \ln x 2, \ln x 4$ and $\ln y$ still do not reach steady state, and all data need two order difference. Finally, all data is stable, so we can carry out the co-integration test below. The data sequence composed of these data is called the two order single integer sequence.

\subsubsection{Co-Integration Test}

1) Determining the optimal delay order

The results of unit root test of time series variables prove that there may be a long-term stable relationship between these five time series variables, that is, co-integration relationship. Under these conditions, we can make a co-integration test for these time variables to see whether there is a long-term stable equilibrium relationship among time series.

In addition, only determining the order of optimal lag period of VAR model is the premise of co-integration test, so we first choose the lag order. Figure 1 is the result of choosing the best lag time for VAR model.

The lag length criterion is the best criterion for determining the delay order of the VAR model. From Figure 4, it can be seen that the upper right corner of the lag phase value has the " $¥$ " mark, indicating that the lag length criterion is the 


\begin{tabular}{|c|c|c|c|c|c|c|}
\hline Variable & $\begin{array}{l}\text { ADF Unit } \\
\text { root test }\end{array}$ & $\begin{array}{c}1 \% \\
\text { Critical value }\end{array}$ & $\begin{array}{c}5 \% \\
\text { Critical value }\end{array}$ & $\begin{array}{c}10 \% \\
\text { Critical value }\end{array}$ & $\begin{array}{c}\text { The } \\
\text { value of } P\end{array}$ & $\begin{array}{c}\text { Test } \\
\text { conclusion }\end{array}$ \\
\hline $\operatorname{Lnx} 1$ & -0.756978 & -3.831511 & -3.029970 & -2.655194 & 0.8084 & Unstable \\
\hline $\operatorname{Lnx} 1(1)$ & -3.747762 & -3.857386 & -3.040391 & -2.660551 & 0.0125 & stable \\
\hline $\operatorname{Lnx} 1(2)$ & -5.393738 & -3.886751 & -3.052169 & -2.666593 & 0.0005 & stable \\
\hline $\operatorname{Lnx} 2$ & -0.273295 & -3.857386 & -3.040391 & -2.660551 & 0.9114 & Unstable \\
\hline $\operatorname{Lnx} 2(1)$ & -2.538091 & -3.857386 & -3.040391 & -2.660551 & 0.1236 & Unstable \\
\hline $\operatorname{Ln} \times 2$ & -6.177128 & -3.886751 & -3.052169 & -2.666593 & 0.0001 & stable \\
\hline Lnx3 & 0.275645 & -3.831511 & -3.029970 & -2.655194 & 0.9702 & Unstable \\
\hline $\operatorname{Ln} x 3(1)$ & -3.236993 & -3.857386 & -3.040391 & -2.660551 & 0.0344 & stable \\
\hline $\operatorname{Ln} \times 3(2)$ & -6.446509 & -3.886751 & -3.052169 & -2.666593 & 0.0001 & stable \\
\hline $\operatorname{Lnx} 4$ & -1.055475 & -3.857386 & -3.040391 & -2.660551 & 0.7093 & Unstable \\
\hline $\operatorname{Lnx} 4(1)$ & -2.379598 & -3.857386 & -3.040391 & -2.660551 & 0.1606 & Unstable \\
\hline $\operatorname{Lnx} 4(2)$ & -5.231715 & -3.886751 & -3.052169 & -2.666593 & 0.0007 & stable \\
\hline Lny & -1.561681 & -3.857386 & -3.040391 & -2.660551 & 0.4807 & Unstable \\
\hline Lny (1) & -2.122674 & -3.857386 & -3.040391 & -2.660551 & 0.2387 & Unstable \\
\hline Lny (2) & -5.728782 & -3.886751 & -3.052169 & -2.666593 & 0.0003 & stable \\
\hline
\end{tabular}

Figure 3. Unit root test results of each time series variable.

\begin{tabular}{ccccccc} 
Lag & LogL & LR & FPE & AIC & SC & HQ \\
\hline \hline 0 & 10.37507 & NA $^{*}$ & 0.012277 & -1.562512 & -1.522103 & -1.577473 \\
1 & 12.44276 & 3.446148 & $0.010304^{*}$ & $-1.740460^{*}$ & $-1.659643^{*}$ & $-1.770382^{*}$ \\
2 & 12.54764 & 0.157314 & 0.012054 & -1.591273 & -1.470046 & -1.636156 \\
3 & 12.55157 & 0.005240 & 0.014456 & -1.425261 & -1.263626 & -1.485105 \\
4 & 12.56557 & 0.016334 & 0.017513 & -1.260928 & -1.058884 & -1.335732 \\
5 & 13.42255 & 0.856982 & 0.018754 & -1.237092 & -0.994639 & -1.326857 \\
6 & 14.25773 & 0.695980 & 0.020668 & -1.209621 & -0.926759 & -1.314347
\end{tabular}

Figure 4. The selection of the optimal lag period of VAR model

optimal lag period established by the model. That is to say, the first order VAR model should be established.

2) Co-integration test

Co-integration test is a test of the relationship between two or more than two variables with different but similar long-term trend. The premise is that the tested variables must be of the same order and single integer. It is confirmed by unit root test that the two variable conforms to the premise of co-integration test. Co-integration test results by Eviews 9.0 are shown in Figure 5.

It can be concluded that there are at least three co-integration relationships among VAR models consisting of five time series variables, $\ln x 1, \ln x 2, \ln X 3$, $\ln \times 4$ and LNY. So it can be affirmed that there is a long-term equilibrium relationship between these five time series variables.

\subsubsection{Impulse Response Analysis}

1) Stability test of VAR model 


\begin{tabular}{|c|c|c|c|c|}
\hline $\begin{array}{l}\text { Hypothesized } \\
\text { No. of CE(s) }\end{array}$ & Eigenvalue & $\begin{array}{l}\text { Trace } \\
\text { Statistic }\end{array}$ & $\begin{array}{c}0.05 \\
\text { Critical Value }\end{array}$ & Prob. ${ }^{* *}$ \\
\hline None * & 0.999802 & 208.4121 & 69.81889 & 0.0000 \\
\hline At most 1 * & 0.878957 & 71.99834 & 47.85613 & 0.0001 \\
\hline At most 2 * & 0.793756 & 38.21265 & 29.79707 & 0.0043 \\
\hline At most 3 & 0.496397 & 12.95353 & 15.49471 & 0.1165 \\
\hline At most 4 & 0.116291 & 1.978042 & 3.841466 & 0.1596 \\
\hline
\end{tabular}

Figure 5. Co-integration test result.

From Figure 6, we can see that the unit root reciprocal of VAR model all falls within the circle, which indicates that the model is stable. Next, based on the VAR model, we analyze the impulse response of variables.

2) Impulse response analysis

Impulse response function can reflect the influence of independent variables on the current value and future value of variables when they are impacted by a standard deviation. Figures 7-10 are the result of the test of the impulse response analyzed by Eviews9.0. The horizontal axis indicates the number of selected periods, and the longitudinal axis indicates the degree of response to the manufacturing industry when the production service industry is subjected to external shocks.

Figure 7 shows the pulse analysis results of transportation and manufacturing industry in Shaanxi province. As can be seen from the graph, when the transportation industry is impacted, the manufacturing industry's response is slow, and it almost starts to react at the end of the first period.

At the same time, at the end of the second to third period, the reaction curve is negative, indicating that the manufacturing industry is more inclined to stabilize the delivery of postal storage. Once the service industry is affected by external shocks, it will have a negative impact on the manufacturing industry.

But as time goes on, this negative response is gradually weakening. To the fourth stage, it has changed to a positive effect and gradually stabilized in the sixth period. It shows that manufacturing industry will adapt and match quickly. It shows the negative impact on the value chain of the lower reaches of the value chain on the added value of the manufacturing industry at the beginning, but the extent of the impact will slowly tend to slow, without too much change.

Figure 8 shows the results of pulse analysis of the real estate industry and manufacturing industry in Shaanxi province. It can be seen from the diagram that when the real estate industry is affected by external shocks, the response of the manufacturing industry is very slow and was not until the end of the third period that it began to show positive fluctuations. This fluctuation is positive and negative alternation over time, indicating that the interaction degree and correlation level between Shaanxi's real estate industry and manufacturing industry are relatively low.

Figure 9 shows the results of the pulse analysis of the financial and manufacturing industries in Shaanxi province. It is shown by the picture that the impact 
Inverse Roots of AR Characteristic Polynomial

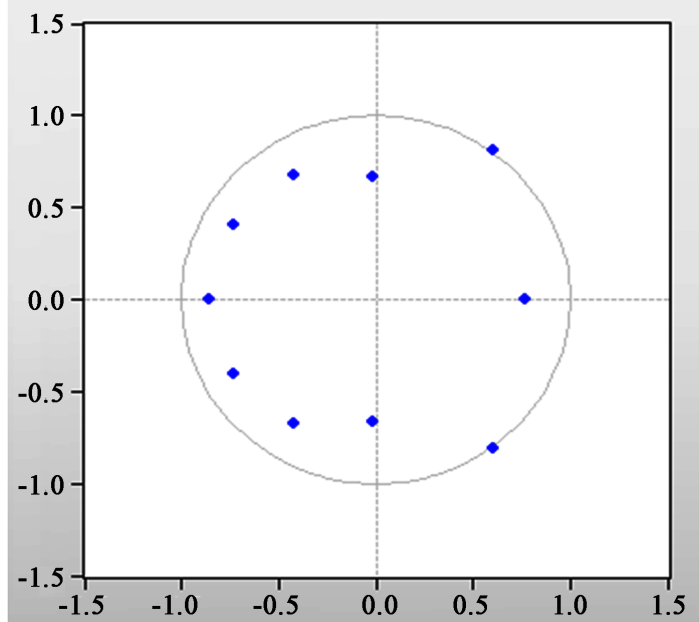

Figure 6. Stability test results.

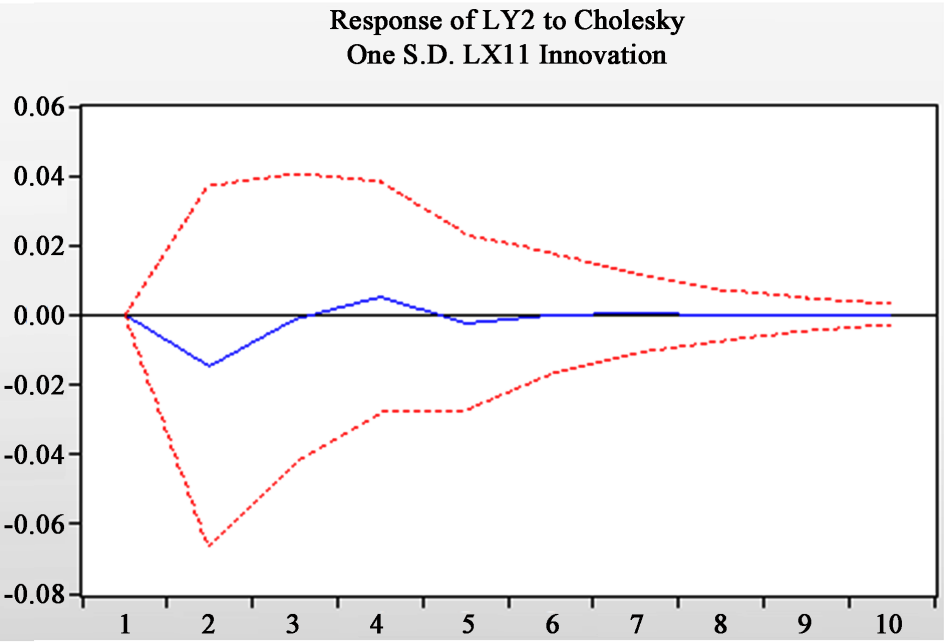

Figure 7. Results of impulse response analysis 1.

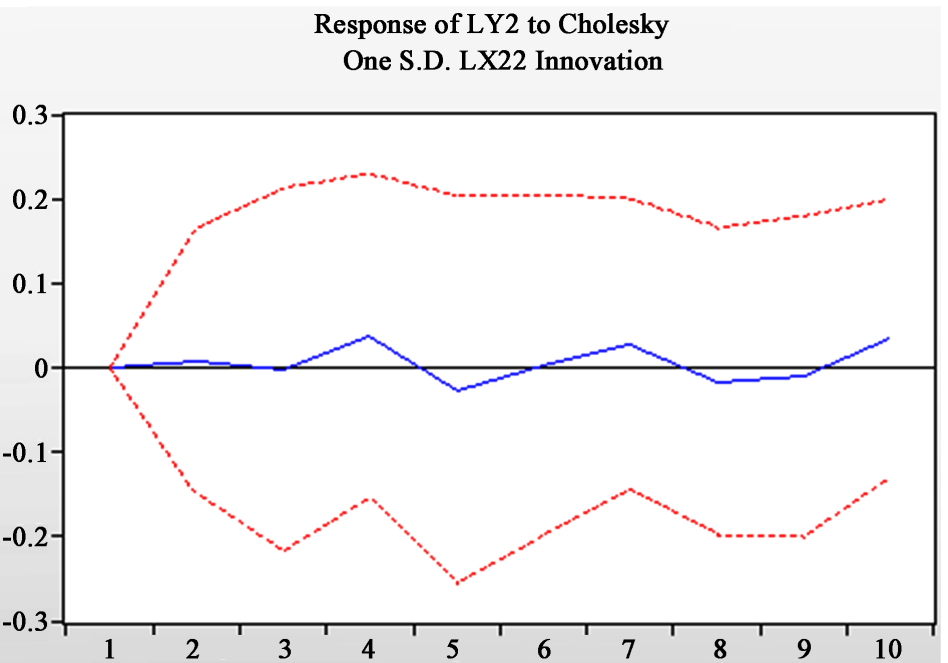

Figure 8. Results of impulse response analysis 2 . 


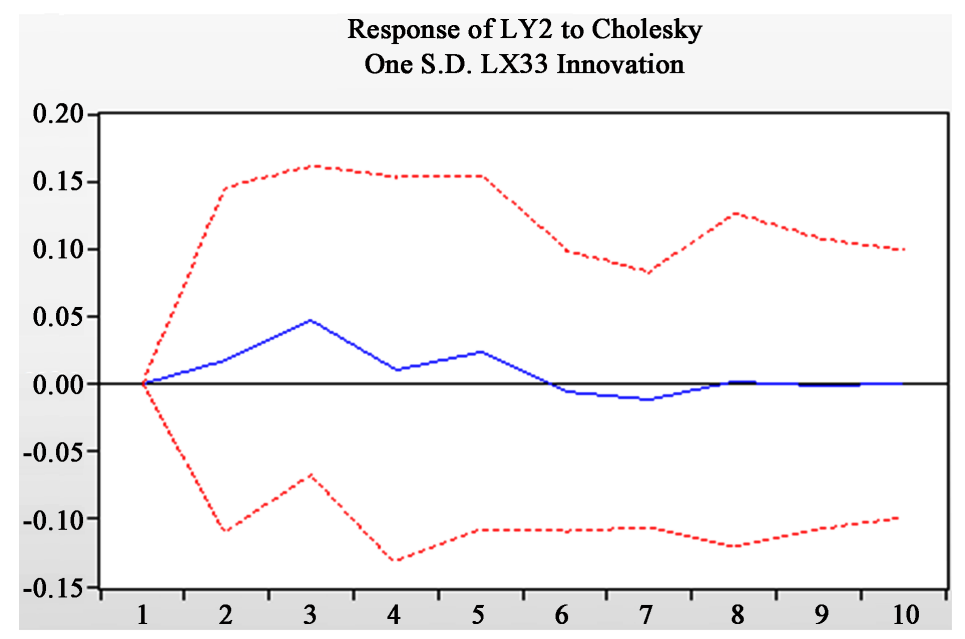

Figure 9. Results of impulse response analysis 3.

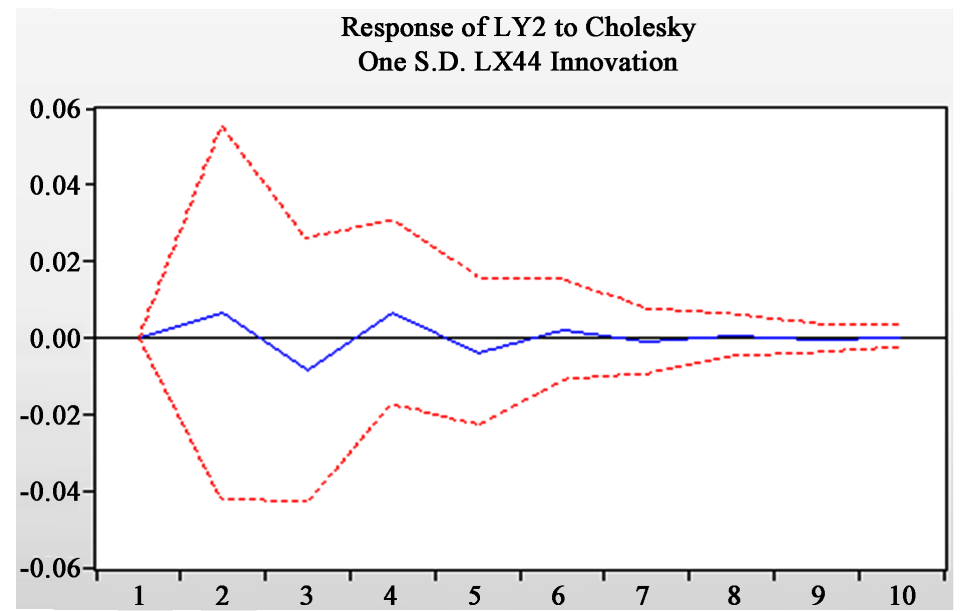

Figure 10. Results of impulse response analysis 4 .

of the financial industry on the manufacturing industry is obviously positively affected by the impact of the financial industry in Shaanxi province. It shows that the financial industry has a very obvious role in promoting the manufacturing industry, and it is encouraging that the financial industry development needle will have a great effect on the development of manufacturing industry in the manufacturing industry.

Generally speaking, the positive impact of the midstream technology service industry and the real estate industry will have a positive impact on the manufacturing industry after the market transmission.

Figure 10 shows the pulse analysis chart of Shaanxi's science and technology service industry and manufacturing industry. It can be seen that the impact of current manufacturing industry on the technology service industry is first positive, and the development of technology service industry will play a leading role in manufacturing industry. But the pulse image fluctuates with time, which shows that the development level of Shaanxi's science and technology service industry is not yet stable, and it has not reached the level of maturity. Therefore, 
Shaanxi, as a major province of science and education, should focus on promoting the development of science and technology service industry.

Overall analysis of 4 pulse analysis chart, when the production service industry has been affected, in addition to the transportation industry, other manufacturing industry reaction first performance is positive, so the production service industry has a positive effect on the manufacturing industry in general.

In general, the fluctuation of the four impulse response maps is more intense, which shows that the interactive relationship between the productive service industry and the manufacturing industry will change with the time. This also shows that the development level of the productive service industry in Shaanxi is still in the primary stage of development, and the level of interaction between the two industries is still low. The development level of producer services in Shaanxi province needs to be improved rapidly. The interaction degree between producer services and manufacturing industry needs to be strengthened.

\section{Main Conclusions}

First, the manufacturing industry has a significant increase in the demand for the productive service industry with high knowledge elements. It shows that the demand for the improvement of technology upgrading and management ability of the manufacturing industry in Shaanxi has become urgent. The knowledge elements upstream are gradually becoming the power source of the manufacturing industry to improve the innovation level and enhance the competitiveness of the enterprises. At the same time, scientific research and technology service industry, which represent the driving role of modern service industry to the manufacturing industry, are rising obviously, and promoting the construction of modern productive service industry has become a core link in the upgrading of manufacturing industry in Shaanxi.

Secondly, the traditional producer services are still a pillar industry of Shaanxi's economic development, showing a high industrial correlation status to other sectors of the economy. It shows that the overall production service industry in Shaanxi is still in a low level, and the proportion of modern service industry is still low, especially the poor driving ability of the financial industry, which does not reflect its role in driving the national economy.

In general, the interaction between manufacturing and productive services is still at a low level, and the impact of the productive service industry is beyond the manufacturing industry, and the impact of the incremental changes in the production service industry on the manufacturing industry is low and unstable. It can be seen that the low level of producer services in Shaanxi province has become a major bottleneck restricting the interactive development of producer services and manufacturing industry.

\section{Fund Project}

1) Scientific Research Program Funded by Shaanxi Provincial Education De- 
partment (Program No. 17JK0677).

2) Science and Technology Agency Research Program of Shaanxi Province (2015KRM022) "Study on Supply Chain Collaboration and Innovation Based on Market Orientation in Shaanxi Equipment Manufacturing Industry Cluster”.

\section{References}

[1] Chen, X. and Huang, J.F. (2004) Division of Labor, Interaction and Integration: An Empirical Study on the Evolution of the Relationship between Service Industry and Manufacturing Industry. China Soft Science, No. 10, 65-71.

[2] Carlsson, K. (1999) Manufacturing in Decline? A Matter of Definition. Economy Innovation and New Technology, 8, 175-196. https://doi.org/10.1080/10438599900000008

[3] Klodt, H. (2000) Industrial Policy and the East German Productivity Puzzle. German Economic Review, 1, 315-333. https://doi.org/10.1111/1468-0475.00016

[4] Markusen, J.R. (1989) Trade in Producer Services and in Other Specialized Intermediate Inputs. The American Economic Review, 79, 85-95.

[5] Juleff, L.E. (1996) Advanced Producer Services: Just a Service to Manufacturing. The Service Industries Journal, No. 16.

[6] Eswaran, M. and Kotwal, A. (2001) The Role of the Service Sector in the Process of Industrialization. University of British Columbia.

[7] Beyers, W.B. (1992) Producer Services. Progress in Human Geography, 16, 573-583. https://doi.org/10.1177/030913259201600407

[8] Henning, L.O. (2008) Producer Services: Growth and Roals in Long-Term Economic Development. Journal of the Service Industries, 28, 463-477. https://doi.org/10.1080/02642060801917588

[9] Zheng, J.C. and Xia, Q. (2005) On the Development of Producer Services and the Deepening of Division of Labor. Technological Progress and Countermeasures, No. 2, 13-15. 